\title{
The Christian Understanding of Happiness
}

\begin{abstract}
The relationship with God allows man to find the sense of life. Christianity is a humanism it positions man in the very centre of the world according him the highest place - of the being created after God's image. The revelation of God's Love endows man with a new way of enriching himself and others. Thus the desire for happiness gains a new perspective of the divine longing for good.

Happiness which Christ promises exceeds the limits of our imagination. It is inconceivable and incomprehensible to those living on earth. Heaven is beyond every word, beyond our conception for it bears the meaning which man cannot fully understand. It is the most supreme happiness, absolutely perfect and complete which no one has ever known.

A Christian has to achieve in his life something more than the worldly aims. Whoever limits their life to the earth, focuses only on enjoying and using this life to the full; squeezing from it the last drop heedless of the needs of others.
\end{abstract}

\section{Keywords}

Happiness, heaven, Christianity, Church Fathers, Jesus, The Old Testament, the Church.

The theme of happiness of people and societies has preoccupied the human thought since the beginning of times. Socrates, Montaigne, Bentham, Mill, or the authors of the American Declaration of Independence - they all tried to tackle this problem. However, whilst the past-centuries reflections on the subject revolved rather around the ways and conditions of achieving individual 
happiness, the last decades have brought about the numerous research upon the happiness as the aim of politics and social progress. Over 200 universities worldwide, including the University of Cambridge, have established research institutes for studying the subject of social happiness. The scientific inquiries have recently been intensified due to the global economic crisis. Lord Richard Layard, an economist from the London School of Economics and political advisor, tried to convince the last Labour governmentin the United Kingdom that the economic growth is not necessarily the first aim of politics. He justified his view with the result of the last 50 years' analysis showing that - despite spectacular rise of living standards - the feeling of happiness amongst the citizens of the United Kingdom or of the United States has not grown. Following this idea, David Cameron, while taking over the leadership of the Tories in 2005, declared: 'Wellbeing can't be measured by money or traded in markets. It's about the beauty of our surroundings, the quality of our culture and, above all, the strength of our relationships. Improving our society's sense of wellbeing is, I believe, the central political challenge of our times. It's time we admitted that there's more to life than money' ${ }^{1}$.

The moments of happiness that man experiences are parts of his life, giving sense to it and for those moments it is worth living. Happiness seems to be very close to life, merging with it, constituting one wholeness and adding to it a unique quality. Although very difficult to name and describe, happiness directly corresponds with the feeling of contentment, with everyday smile and joy. The crucial elements of happiness occur in the closest - in spatial context relationships with other people.

One of the mechanisms of measuring our own level of happiness is comparing ourselves to others. Sometimes it is a kind of therapy, especially when we face some, worse than ever, situations such as illness or another affliction. The feeling of uncertainty, which accompanies this experience, increases our need to compare our situations to those of others. The literature usually tells about three basic reference groups: membership group - to which we currently belong, with which we identify ourselves and with which we are connected (family, friends, members of the same group, etc.); aspiration group - to which we wish to belong (representatives of higher social class, superiors, film and music stars, commonly respected people, etc.) that motivates us and spurs the

${ }^{1}$ Ph. Johnston, M(i)arkowanie szczęścia, (“The Daily Telegraph”, 23 XI 2010), "Forum” (2011) nr 1, p. 17. 
need to be equal, sometimes causing the feeling of bitterness when we learn that catching up with them is not really possible; and the third - disclaimant group - comprising people whom we tend to avoid since we do not value them highly ${ }^{2}$. The effect of making those constant comparisons and contrasts with others is the feelings of either comfort or discomfort, depending on the situation. Sometimes - in order to gain more satisfaction - people purposefully seek such reference groups which are less demanding and in which passiveness of an individual is easily excused. Ryszard Kapuściński, in his book "The Emperor", described such a propensity of the Ethiopian ruler Haile Selassie: 'the King of Kings preferred bad ministers. And the King of Kings preferred them because he liked to appear in a favorable light by contrast. How could he show himself favorably if he were surrounded by good ministers?'3.

The essence of religion - as claimed by E. Gilson - is 'personal attitude of man to the transcendent, real and personal Absolute (God)' ${ }^{4}$. It pertains especially to Christianity which became for its followers a solid, supporting ground for their personal development ${ }^{5}$.

Encountering God allows man to find the meaning of life. Christianity is a humanism - it positions man in the very centre of the world, putting him in the highest place - that of a being created after God's image. The revelation of God's Love endows man with a new way of enriching himself and others. Thus the desire for happiness gains a new perspective of the divine longing for good.

\section{The Holy Bible on happiness and sorrow of the soul}

The Moses followers believe that happiness can be achieved and deem it the ultimate goal of man. According to them, the pursuit of happiness is a moral duty, and whether we are happy or not depends very little on circumstances in which we find ourselves. Judaism does not regard life merely as a transient phase between birth and eternity. Already during our terrestrial life can the

${ }^{2}$ Cf. K. White, D. W. Dahl, To Be or Not Be? The Influence of Dissociative Reference Groups on Consumer Preferences, "Journal of Consumer Psychology" (2006), vol. 16, nr 4, p. 404-414.

${ }^{3}$ R. Kapuściński, Cesarz, Biblioteka Gazety Wyborczej, Warszawa 2008, p. 33.

${ }^{4}$ Z. J. Zdybicka, Religia i religioznawstwo, Lublin 1988, p. 367.

${ }^{5}$ K. Olbrycht, Religia a wspieranie rozwoju człowieka, in: Religia a sens bycia człowiekiem, Z. J. Zdybicka (ed.), Redakcja Wydawnictw KUL, Lublin 1994, p. 103-112. 
happiness be attainable. It is after all in the very description of the world creation, that the world entrusted to man is named as good several times ('And God saw that it was good') ${ }^{6}$. The key to happiness is thus primarily a wise appreciation of everything which has been given to us, not focusing on something we do not possess. Even our daily distresses and failures cannot deprive us of the possibility of feeling happy, if only we tried to treat them as an enriching experience.

The problem of happiness appears in the entire Scriptures, starting with the loss of paradise and finishing with its retrieval. And amongst the presented happy figures and happiness-bringing situations there is a visible hierarchy. A quick death at war is better than a long existence under the enemy's oppression $^{7}$ as a short life of a hero is more beautiful than a long vegetation in beyond-the-worlds, decrepitude and chronic illness or being fated with a bad woman ${ }^{8}$. Health and strength are better than any wealth and money ${ }^{9}$. Generally speaking, the Old Testament puts a huge emphasis on happiness coming from wealth and well-being, as well as on moderate wisdom with the religious yet a bit naturalistic tint. In his life man appeals to God when making his basic choices. Moses says to his people: 'See, I have set before you this day life and good, death and evil. If you obey the commandments of the Lord your God which I command you this day, by loving the Lord your God, by walking in his ways, and by keeping his commandments and his statutes and his ordinances, then you shall live and multiply, and the Lord your God will bless you in the land which you are entering to take possession of it ${ }^{\prime 10}$.

According to the old Israeli tradition the concept of happiness referred to the earthly reality: Israel will receive from God the promised land so as to enjoy in peace the earthly riches and long life, free of sickness and misery of all kinds ${ }^{11}$. The faithfulness to the covenant will allow to obtain the goods which shall guarantee happiness: a fertile land, plentiful in water springs and

${ }^{6}$ Cf. Gen 1: 4, 10, 12, 18, 21, 25, 31; L. Ferry, Człowiek-Bóg czyli o sensie życia, przekł. A. Miś, H. Miś, PIW, Warszawa 1998, p. 145-179.

7 S Sam 31:4.

8 Eccles 7: 27.

9 Sir 30:14 ff.

${ }^{10}$ Deut 30:14-16; Cf. A. Iniesta, Jezus Chrystus - herold szcześliwości, “Communio” (1962) nr 2-3 (92-93), p. 5.

11 Exod 20:12; 23: 22-26. 
creeks, flowing through the valleys and the hills, a land yielding wheat, barley, vines and fig trees and pomegranates, a land of olive trees and honey. God promises: 'You shall eat your fill and bless the Lord your God for the good land that he has given you ${ }^{12}$. Happiness, understood in this way, has its material dimension, it is concrete, tangible. However, the description of Eden conveys, first of all, the spiritual and religious emotional state: happiness of Adam and Eve consisted mainly in their closeness to God, rather than be limited to living in a beautiful garden among 'every tree that is pleasant to the sight and good for food ${ }^{13}$. Happiness essentially depends on observing the law established by God whilst sins committed by man cause his inner torments. And it is God who becomes again man's Comforter. Thus from the word "comfort" comes the name of God. Moses proclaims on the desert: 'I am who I am' ${ }^{\text {'14 }}$. Yet to the prophet who is entitled to comfort God's people in exile God reveals His new name: 'I, I am he who comforts you' ${ }^{\text {'15. }}$

In the prophetic tradition happiness bears eschatological features. At "the end of days" ${ }^{16}$ the people, purified through experience, will convert and then all God's promises of people's happiness will be fulfilled. Jeremiah prophesies the new covenant, outlining the visions of a complete eschatological joy: 'They shall come and sing aloud on the height of Zion, and they shall be radiant over the goodness of the Lord, over the grain, the wine, and the oil, and over the young of the flock and the herd; their life shall become like a watered garden, and they shall never languish again. Then shall the young women rejoice in the dance, and the young men and the old shall be merry. I will turn their mourning into joy, I will comfort them, and give them gladness for sorrow. I will give the priests their fill of fatness, and my people shall be satisfied with my bounty ${ }^{17}$. It is from God that happiness and unhappiness may come, and man's life lies in His hands, and it has its source in God's saving plan ${ }^{18}$.

12 Deut 8:7-10, cf. 6: 2-3.

13 Exod 2:9.

${ }^{14}$ Exod 3:14.

15 Isa 51: 12; Cf. P. Kasiłowski, Odmienieni przez smutek, "Pastores" (2011) nr 52, p. 97-101.

${ }^{16}$ Dan 2:28.

17 Jer 31: 12-14.

18 W. Langer, Szczęście, in: Praktyczny słownik biblijny, A. Grabner-Haider (ed.), przekł. T. Mieszkowski, P. Pachciarek, Pax, Warszawa 1994, k. 1265 - 1266. 
In biblical scholar tradition happiness is one of the most critical issues. A means to achieve happiness is wisdom: 'Happy are those who find wisdom, and those who get understanding ${ }^{19}$. Wisdom assures all goods indispensable for experiencing happiness. It consists in knowing and respecting the law. Whoever wants to achieve happiness, should renounce the wicked and not to follow their advice ${ }^{20}$. Wisdom is 'a tree of life ${ }^{21}$. Happiness is a reward for justice, as unhappiness is a reward for sins. The Old Testament people most often expected from God happiness on earth. Still, Kohelet had a different view on this issue, preaching that neither goodness, nor wisdom, nor piety can guarantee full happiness on earth. He agrees only with the fact that man can achieve some amount of happiness, and that he must do everything not to waste it. ${ }^{22}$.

The Biblical descriptions of man's condition are acutely realistic. Some of its texts reveal the everlasting man's experiences - depression, despondency, sadness. A fine exemplification may be the words from the Book of Wisdom which most accurately describe the mental depression of the modern man: 'For the whole world was illuminated with brilliant light, and went about its work unhindered, while over those people alone heavy night was spread, an image of the darkness that was destined to receive them; but still heavier than darkness were they to themselves ${ }^{23}$.

The feeling of sadness and dejection are frequent in the Bible, such as the sad words of a psalmist: 'My tears have been my food day and night, while men say to me continually, "Where is your God?"'24. The sadness and despondency derive from the Biblical term 'pentheo' meaning 'to mourn, 'to wail' or 'to lament' and we can distinguish three groups of people characterized by these terms: mourning over the deaths of one's relatives or of those well respected, or because of a sin and its consequences.

Another cause of sorrow and despondency - in biblical verses - are the people's misfortunes. Thereby, a psalmist is lamenting before God that people repay with evil for the goodness he has done for them - they abandoned him

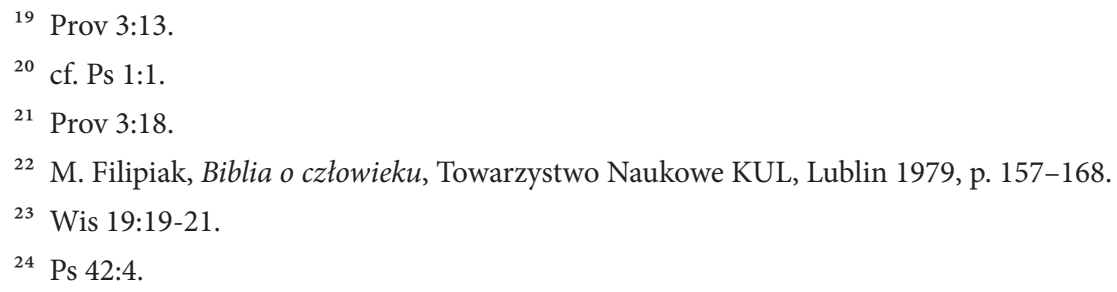


when he was in need whilst he had assisted them during their grief, treating them as his next of $\mathrm{kin}^{25}$. The Book of Sirach resounds with an appeal for solidarity with people afflicted with pain - we cannot avoid those weeping and mourning, but rather assist them in their hardships ${ }^{26}$.

The source of sorrow is also sins and their consequences. Prophet Hosea foretold the citizens of Samaria the punishment for worshipping false gods and after the destruction the people of Samaria started mourning ${ }^{27}$. In his words to Amos God promises the punishment of His people who have deviated from the way of good, harmed and deceived the poorest and the most vulnerable. Thus $\mathrm{He}$ is going to punish them with an earthquake which will make all the citizens mourn ${ }^{28}$. The same sadness and grieving can be found in the vision of God's judgment over Israel, the vision of destruction, exile and calamities ${ }^{29}$. At the end of the Book of Sirach the author declares his faithfulness to God, manifested also through sorrow and mourning over those who disregarded wisdom before ${ }^{30}$. Man's happiness interweaves with misfortune. Yet everything depends on God, whilst man's role is to find the truth about himself and his relationship with the Creator.

\section{Happiness of Jesus}

In every attempt made by the Evangelists to portray Jesus, the very first thing be the most mystical element - is Jesus' intimacy with God. God whom $\mathrm{He}$ names His Father, when the voice coming from a cloud is calling His "Beloved Son" and proves what is stated throughout the whole New Testament that Jesus behaves like a trusting God's child. Jesus acts like this during His entire life, and when finishing it on earth, He entrusts His Soul in His Father ${ }^{31}$. The truth about Jesus is crucially important for understanding the Christian happiness

25 cf. Ps 34:12-14.

${ }^{26}$ Cf. Sir 7:34.

27 Cf. Hos 10:5.

28 Cf. Amos 8:8.

29 Cf. Amos 9:5.

${ }^{30}$ Cf. Sir 51:19.

${ }^{31}$ Cf. D. L. Carmody, J. T. Carmody, Mistycyzm w wielkich religiach świat, przekł. E. Łukaszyk, Wydawnictwo WAM, Kraków 2011, p. 233-245. 
of those whose vocation and aim of all efforts are to unite with God in Christ, to become so to speak "deified" - as we read in the second letter of St. Peter: "to become partakers of the divine nature ${ }^{32}$. Theology has reconfirmed this truth many times, making it the primary goal of Christianity: 'God became man so that man might become God'. The so called "Nicene creed" emphasizes that in Christ the nature of man has united with the nature of God, forming the perfect and inseparable union, so that people, through their nature, might participate in His Divinity ${ }^{33}$.

Jesus experienced the entire humanity, with all joys and sorrows of the terrestrial life. The verses of the Gospel tell about Jesus' grief when coming to the grave of his friend, Lazarus. St. John writes: 'Jesus weeps ${ }^{34}$. Jesus' sorrow is also caused, as the Evangelists recount, by the hardness of the hearts of the Jewish leaders: the scribes, the Pharisees and the priests. It was not Jesus who rejected them, but they rejected Him, although He made every effort to convince them, like sending the leper after healing: '(...) go, show yourself to the priest, and offer for your cleansing what Moses commanded, for a proof to the people ${ }^{35}$. He addressed in a similar manner the scribes - after forgiving the sins of a paralytic and healing him: 'But that you may know that the Son of man has authority on earth to forgive sins ${ }^{36}$. There were all the "signs" to convince, to give the testimony to the doubting ones so that they might receive the grace of salvation. Jesus' signs derived from His deep solidarity with all people. As recounted by St. Mark: Jesus 'grieved at their hardness of heart ${ }^{37}$, or as described in another place: 'He came to his own home, and his own people received him not ${ }^{38}$ telling about rejection of the Truth and the Good by those who should have first recognized Him. A similar message is conveyed in Jesus' lamentation over Jerusalem: 'O Jerusalem, Jerusalem, killing the prophets and stoning those who are sent to you! How often would I have gathered your children together as a hen

32 Pet 1:4.

33 Cf. D. B. Hart, Chrześcijańska rewolucja a złudzenia ateizmu, przekł. A. Gomola, Wydawnictwo WAM, Kraków 2011, p. 250-268.

\footnotetext{
34 John 11:23.

35 Mark 1:44.

36 Mark 2:11.

37 Mark 3:5.

38 John 1:11.
} 
gathers her brood under her wings, and you would not! ${ }^{39}$. Sorrow caused by other people's sins is the theme of the other parts of the New Testament. St. James appeals in his letter to the sinners so that they mourn and weep over their own sins ${ }^{40}$. Such grief is illustrated in the parable of the Prodigal Son ${ }^{41}$. His living home contravenes the truth according to which a son belongs to his father with his every part, and exposes his indifference to his father's love and his disdain for his father's gifts. When translating this parable into God-man relationship, we can recognize God's grief which appears whenever man - His child - sins and follows the wrong paths ${ }^{42}$. And the moment of the most acute sorrow of Jesus Christ was certainly His suffering and death on the cross, expressed by His final words: 'My God, my God, why hast thou forsaken me? ${ }^{43}$.

The core implication of Jesus' happiness fulfilling His Father's will. And the "Maker" of this happiness was the Holy Spirit. Jesus explicitly stated that His happiness is the salvation of sinners, 'to seek and to save the lost ${ }^{\text {'44. Jesus }}$ experienced joy in relations with people close to Him (Lazarus), sharing with them the daily joys: feasting, pilgrimaging to Jerusalem, living in a family and among people ${ }^{45}$.

Happiness, as exhibited in the New Testament, is understood in completely new categories. Now God Himself, the highest and infinite value, happiness in itself, is offered directly to man through the life of Jesus of Nazareth. Jesus is the prophet of happiness, the way to and the happiness Himself ${ }^{46}$. It is thanks to Him that we learn: 'It is more blessed to give than to receive ${ }^{37}$; 'For whoever would save his life will lose it, and whoever loses his life for my sake will find

\footnotetext{
39 Matt 23:37.

40 Cf. Jas 4:9.

${ }^{41}$ H. J. M. Nouwen, Powrót syna marnotrawnego, Poznań 2000, p. 42-43.

42 A. Rybicki, Świątobliwy, ale nieszczęśliwy, "Pastores” (2011) nr 52, p. 81-88.

${ }^{43}$ Mark 15:34.

${ }^{44}$ Luke 19:10.

45 G. Strzelczyk, Szczęście Jezusa, "Pastores” (2011) nr 52, p. 15-21.

${ }^{46}$ Por. S. Kunka, Być szczęśliwym dziś. Marzenie czy rzeczywistość?, “Obecni” (2012) nr 24,

47 Acts 20:35.
} p. 27-39. 
$\mathrm{it}^{\text {'48; }}$; A servant is not greater than his master; (...) If you know these things, blessed are you if you do them ${ }^{49}$.

The road to happiness of every Christian is love which is the obligation of the love commandment. Yet, it is not the mere loving your neighbour as yourself which is the most concrete and final form of love - as prescribed by the Old Testament and preserved and sanctified by the New Gospel. Rather, the new norm of love, to be followed by every Christian, is to love your neighbor just like Jesus does. When loving our neighbours like ourselves we still confront them with us, with this element of the old but still existing egoism in which we look like in the mirror whereas when confronting with Jesus, we relinquish completely our old selves in the service of God and of our brothers. The finest manifestation and testimony of such utter love is Christ's Passion and Death: 'Greater love has no man than this, that a man lay down his life for his friends ${ }^{50}$. Such love is praiseworthy everywhere and in every aspect of life. It is the most cardinal and the firstlaw on which St. Paul writes: 'Owe no one anything, except to love one another; (...) The commandments, "You shall not commit adultery, You shall not kill, You shall not steal, You shall not covet," and any other commandment, are summed up in this sentence, "You shall love your neighbour as yourself." Love does no wrong to a neighbour; therefore love is the fulfilling of the law! ${ }^{51}$. It is not merely theoretical consideration upon love, but emphasizing the Christian practice (praxis). The commandment of love requires the Christian-like activity. It is intrinsically linked with the radical demand of justice. In His sermon on the Mount, about the Eight Beatitudes, be the peculiar Code of Happiness, Jesus tells about the happiness attained through poverty, pain, self-restraint, persecution, weeping and sorrow ${ }^{52}$.

The Christian understanding of the social status of man has its roots as well in the truth of Incarnation. The community of Christians is the Body of Christ, the branches of the Vine. The blossoming of spiritual life is the life of

${ }^{48}$ Matt 16:25.

${ }^{49}$ John 13:16-17. Cf. R. Herka, O chrześcijańskiej miłości i szczęściu, “Obecni” (2012) nr 24, p. 5-9.

50 John 15:13.

51 Rom 13:8-10) 17.

${ }^{52}$ R. Coste, Miłość która zmienia świat. Teologia miłości, przekł. M. Stokowska, Fundacja Jana Pawła II, Rzym - Lublin 1992, p. 77-122. 
Christ Himself, which He relishes, along with His Father and the Holy Spirit, as the Incarnated Word ${ }^{53}$.

\section{Happiness in the Church Fathers}

Throughout many centuries Christians have been accused of elevating sorrow, emphasizing the role of suffering and depriving man of the right to enjoy life and its charms. Such clichéd views have many sources. One of them was the meek and humble attitude of Christ's first followers. Arystydes wrote about Christians in the first half of the $2^{\text {nd }}$ century: 'But the good deeds which they do, they do not proclaim in the ears of the multitude, and they take care that no one shall perceive them, and hide their gift, as he who has found a treasure and hides it. And they labour to become righteous as those that expect to see their Messiah and receive from Him the promises made to them with great glory. But their sayings and their ordinances, $\mathrm{O}$ king, and the glory of their service, and the expectation of their recompense of reward, according to the doing of each one of them, which they expect in another world, thou art able to know from their writings ${ }^{34}$. All the good made to others, as well as a concern for justice, proved the great optimism of Christians, their hope for building a better world, and the attempts to build a happy society already here, on earth.

At the same time the early Christians renounced the shallow, pagan fascination with material goods, wealth and sensual pleasures. They were not for them. The disdain for the worldly treasures, those wrecking the prospect of God's vocation, is clearly seen in the writings of many Church Fathers. St. John Chrysostom, in his commentary to the evangelical appeal, writes: 'Do not lay up for yourselves treasures on earth' (Matt 6:19a). He taught that greed for riches is instigated by greed for fame. 'This, for instance, is why men devise those herds of slaves, and that swarm of eunuchs, and their horses with trappings of gold, and their silver tables, and all the rest of it, yet more ridiculous; not to satisfy any wants, nor to enjoy any pleasure, but that they may make a show before the multitude ${ }^{255}$.

53 D. L. Carmody, J. T. Carmody, Mistycyzm..., p. 233-253.

${ }^{54}$ Arystydes, Apologia, in: M. Michalski, Antologia literatury patrystycznej, t. 1, Pax, Warszawa 1975, p. 90-91.

${ }_{55}$ Św. Jan Chryzostom, Miłosierdzie. Wypisy z „Homilii na Ewangelię według św. Mateusza“, oprac. E. Staniek, Wydawnictwo WAM, Kraków 2004, p. 29. 
Wealth has no lasting value; it is unsubstantial and transient. Those in possession of earthly riches enjoy them only for a short time, despite their constant efforts to sustain and multiply them. That is why ranking them higher than spiritual wealth is ludicrous and illogical. Rather, spiritual treasures should be managed in such a way so that they would bear good fruits - as Jesus taught in His parable about the Sower - even without knowing whether the investment will bring the profit. Still, each treasure given out with joyous heart is accompanied with hope for a greater joy and happiness which shall last forever ${ }^{56}$.

So as to highlight the rightness of choosing spiritual values over the worldly ones the Christian monks gave up their lives until then, sold their possessions and looked for spiritual ideal in a prayer, fasting and seclusion. They learnt how to put all the trust exclusively in God, just like St. Anthony a Hermit, who went to the Egyptian desert, and many followers, showing to others that health and closeness to God are a natural state man should enjoy ${ }^{57}$.

A happy man may only be the one who has God in himself. This truth was reiterated by Saint Augustine: 'Deum qui habet, beatus est' ('He that hath the God, blessed is he' $)^{58}$. Happiness is given from God and it reaches fulfillment only after death when man meets again with the Creator. St. Augustine presumed that anyone who wants to be happy should want to be immortal as it is highly unlikely that life which is totally happy might end. Immortality is thus necessary for happiness, but it is not sufficient - so as to be happy eternally we need to act virtuously, and God will bestow upon us, securing our efforts, the grace of salvation ${ }^{59}$. According to St. Augustine, the highest goal of man is to reach God. Only following this path can we achieve happiness. The most crucial form of man's activity is thus living by love. Everything what comes from God is good. When man is truly happy it means that he has God, that he is living the good life, that he is fulfilling His will and that he is not being led by unclean spirit ${ }^{60}$.

${ }^{56}$ Por. P. Szczur, Problematyka społeczna w późnoantycznej Antiochii na podstawie nauczania homiletycznego Jana Chryzostoma, Wydawnictwo KUL, Lublin 2008, p. 94-95, 150-156, 243 248.

57 D. L. Carmody, J. T. Carmody, Mistycyzm..., p. 245-253.

58 Św. Augustyn, O życiu szczęśliwym, in: Dialogi filozoficzne, Warszawa 1953, t. 1, p. 17.

${ }^{59}$ Cf. P. Michoń, Ekonomia szczęścia, Dom Wydawniczy Harasimowicz, Poznań 2010, p. $13-14$.

${ }^{60}$ Cf. Św. Augustyn, O życiu szczęśliwym..., p. 17-20. 
In the long discourse on happiness of a Christian there occurred the differentiation between positive and negative sadness. Evagrius of Pontus, after St. Paul ${ }^{61}$, distinguished between the worldly sadness (resulting from unfulfilled worldly desires and carnal lusts) and sadness coming from God (sorrow for one's sins, repentance), but also between the commendable and blameworthy ones. The negative sadness may be the result of unrealistic hopes, consequence of failure, anger or unsatisfied desires for revenge; it stems from dwelling on one's pains and sufferings, from grieving over the lost relatives or over the lost material possessions or it may be even the reaction to sinister dreams caused by demons. People most vulnerable to them are those who are devoutly attached to something in the world, whereas people free of them are those who have managed to liberate themselves from insatiable desires. The harmful effects of the above kind of sadness may be the state of despondency, pessimism or even suicidal temptations. The thing is, that sadness is contradictory to every good. The good, positive sadness leads to man's purgation of all sins, it allows to obtain forgiveness, it helps in prayers, it is a remedy for passions, it wards off bad thoughts, it cures a soul of lassitude and hardness ${ }^{62}$.

A Christian cannot rely himself only on beautiful words, promises and sharp antitheses. Rather, his wisdom should consist in an exemplary, pure and unambiguous life, closely connected with the sacrifice of purging one's soul. The epitome of wisdom is, by St. Gregory of Nazianzus, that of a farmer and shepherd who knows what he is supposed to do so as to produce yield and make a profit. The theologian contrasts it with the wisdom of false speeches and empty, obscure phrases. Even if the latter describe happiness, they do not multiply it, but distance their listeners farther from it ${ }^{63}$. Happiness is not borne by itself, but it is the effect of man's choices. Man becomes free like a form "is freed" of marble by a sculptor's hand and chisel. We are notfree, merely because we can freely choose, but we are truly free when we choose what is right. If we choose wrong - foolishly or deliberately - and contradictory to a human nature which distorts a true form - it make us enslaved to what is transient, temporary, irrational and aimless. In order to choose well, man must clearly see Christ,

${ }^{61}$ Cf. 2 Cor 7:10

${ }^{62}$ R. M. Pancerz, Miejsce smutku w duchowości chrześcijańskiej. Świadectwa wielkich pisarzy monastycznych od Ewagriusza do Jana Klimaka, "Polonia Sacra" (2011) nr 29, p. 277-290.

${ }^{63}$ Św. Grzegorz z Nazjanzu, Mowa 16. Po klęsce gradowej w obecności milczącego Ojca, nr 2, in: Św. Grzegorz z Nazjanzu, Mowy wybrane, Pax, Warszawa 1967, p. 190. 
taking Him as the Sun of life and not stopping in making the right choices ${ }^{64}$. Only then will he be able to build the happiness of his own and of others.

\section{Hope of the Church}

Man's life is continuously striving towards a final goal. The subject of this pursuit, namely man, remains in a dynamic relationship its object, which is good. It is first, an intentional fact (ordo intentionis) that encompasses a rational act of volition, assuming a specified good, and it precedes the executive phase (ordo executionis), based on the choice of measures taken for performing real actions that lead to goal achievement. Following this rhythm man is getting closer to the good the attainment of which is his happiness ${ }^{65}$.

A pilgrim must carry in his heart, first of all, a hope for reaching the aim, so that he could see the sense of overcoming obstacles on his way. This hope preserves the sense of his endeavor, justifies his efforts and enables him to await patiently the final destination of his journey. It is the constant struggle of man and as St. John Paul II admonished: 'the good to which we are all called and the happiness to which we aspire cannot be obtained without an effort and commitment on the part of all, nobody excluded, and the consequent renouncing of personal selfishness ${ }^{36}$.

Immanuel Kant saw in hope the essential element of every quest for the truth. He recapitulated a wide sphere of human reasons in three questions: 'What can I know? What ought I to do? What may I hope?'67. The answer to the first question is provided by science; to the second by morality; the third may be answered only by religion for only religion - in his view - responds to hope. In the older times hope was being downgraded to a mere feeling (Descartes). Hope was also associated with fantasies or tallied with the resignation of rational objectives.

${ }^{64}$ Cf. D. B. Hart, Chrześcijańska rewolucja a złudzenia ateizmu, przekł. A. Gomola, Wydawnictwo WAM, Kraków 2011, p. 42 nn.

${ }^{65}$ T. Ślipko, Etos chrześcijański. Zarys etyki ogólnej, WAM, Kraków 1974, p. 80-84.

${ }^{66}$ Solicitudo rei socialis, 67.

${ }^{67}$ I. Kant, Krytyka czystego rozumu, II, II, II, tłum. R, Ingarden, t. 2, PWN, Warszawa 1957, p. 548. 
Happiness for which a Christian strives is in constant progress, it is the process of getting closer to God, discovering more and more of the Beauty, Good and Truth. In the Christian mysticism happiness is inextricably linked with the person of Jesus, with His Incarnation, Death and Resurrection. Thus the Gospel is also full of sources of hope for man's happiness ${ }^{68}$.

The source of mutual trust, the trust in ourselves and in God, is the fact that Jesus has redeemed us: 'Christ Jesus our hope ${ }^{369}$. Without Jesus, man would be hopelessly lost in sin. God's Spirit reawakens in man joy and confidence of faith: 'and no one can say "Jesus is Lord" except by the Holy Spirit" ${ }^{70}$. Through His help we can find Christ, agree to be captured by Him, and to get near Him so: 'that by it you may grow up to salvation; you have tasted the kindness of the Lord ${ }^{171}$.

Without knowing God, man is in danger of losing the sense of his way of life, of being lured by the worldly goods which turn put to be too flimsy and small to satisfy man's longings. An ostensible power of wealth, giving a semblance of happiness, leads man to despair. Wealth is a challenge for man. It requires maturity on his part, the more so if Jesus paradoxically names happy those who are poor ${ }^{72}$.

Aimless and excessive consumption offers only a caricature of happiness, but is a direct consequence of the original sin as this sin itself consisted in careless consumption, giving a false promise of satiation. And yet man has bigger needs which can be satisfied only by God. Therefore, each kind of consumption requires an answer to question of its sense as well as of good and bad, and of our goal ${ }^{73}$.

The Church has a realistic view of man's needs, not allowing at the same time, the worldly ones to prevail over spiritual. St. Benedict observes the diverse range of people's needs, when he advises: 'He who needs less should thank God and

${ }^{68}$ Cf. Św. Tomasz z Akwinu, Szczęściem poznanie Boga, in: Summa filozoficzna (Contra Gentiles), Kraków 1933, ks. III, p. 319-325.

${ }^{69}$ Cf. 1 Tim 1:1.

${ }^{70} 1$ Cor 12:3.

71 Pet 2:2n.

${ }^{72}$ M. Kopsztejn, Chrześcijański paradoks szczęśliwego ubóstwa, "Pedagogika Katolicka" (2011) nr 8, p. 128-136; Cf. F. Memches, Bogactwo jest wyzwaniem. Rozmowa $z$ rabinem Szalomem Berem Stamblerem, "Uważam Rze” (2011) nr 37, p. 84-85; J. Domański, Z dawnych rozważań o marności i pogardzie świata oraz nędzy i godności człowieka, PAN Instytut Filozofii i Socjologii, Warszawa 1997, p. 15-72.

${ }^{73}$ Cf. R. Leick, Siódmego dnia odpocznij. Rozmowa z Tomaśem Sedlaćkiem ("Der Spiegel”, 19 III 2012), “Forum" (2012) nr 14/15, p. 4-6. 
not be discontented; but he who needs more should be humbled by the thought of his infirmity rather than feeling important on account of the kindness shown him. Thus all the members will be at peace ${ }^{74}$. This instruction of St. Benedict's "Rule" is followed with detailed prescriptions concerning the daily intake of food and drink, time of meals, behavior towards sick monks, etc.

It is not that a Christian must totally discard temporal world; rather, temporality is to be animated so as to provide the good world structures, the good space for human personality development; it is to make man evolve most comprehensively, providing him with personal and family goods, encouraging his involvement in culture, participation in economic and political life. This is part of evangelisationand of the sanctification of man, leading to the ultimate goal of oneness with $\mathrm{God}^{75}$.

Theologians emphasised the necessity of combining hope with love of life, for without love hope is incomplete (Jürgen Moltmann). Conversely, hope was perceived differently by those who despised love and the earth, to whom it was a power destroying the world through revolutionary ways, or those who did not know love - this one which accepts worldly torments and human sufferings as it gives hope for the earth and for the body. Amongst them they were e.g. Marcion, Montanus, Joachim of Fiore or Thomas Müntzer.

Joseph Ratzinger, in his book of 1972 devoted to the theology of Hans Urs von Balthasar, comments on e.g. Marc Chagall's works. In 1973 Chagall painted "The Revolution" depicting, on the left, the crowd of armed people unfurling the red flags, on the right side the images of peace and joy - the sun, love and musicians playing. The great work of the revolution is to be the world transformation, some sort of redemption and salvation of people. The figure with the raised head in the middle, balancing upside down on one hand, draws on the well-known images of V. I. Lenin, the symbol of the revolution. The whole picture was to depict a dead hope of those who had undertaken the work of the revolutionary conversion of the world. It is the dead hope - as proved by Chagall himself for he destroyed the canvas afterwards, saving only the sketch. A few years later the artist did a new painting: with the same setting,

${ }^{74}$ Za: S. Szamota, Święty Benedykt, jego dzieło i „Reguła“, Wydawnictwo Panta, Lublin Frydrychowice 1991, p. 41.

${ }^{75}$ Cf. L. Boriello, G. della Croce, B. Secondin, Duchowość chrześcijańska czasów wspótczesnych, seria: Historia duchowości, t. 6, tłum. M. Pierzchała, Wydawnictwo Homo Dei, Kraków 1998, p. 351-352. 
yet on the right he painted the image of the future redemption, on the left the revolutionized world - looking rather more afflicted with pain than rebellious and revolting. The most significant change takes place in the middle: in place of Lenin the artist put the image of the Crucified Christ. The message is clear: Christ is the hope for the world. Redemption of the world does not come from its transformation or from the absolutized politics. So as to transform the world we need to work conscientiously, devotedly and heroically as transformation has its roots in the mystery of the Cross. Chagall wanted to signal that there are "living hopes" and "dead hopes", fruit-bearing and destructive, liberating and leading us astray ${ }^{76}$.

To discover true happiness is man's vocation, his call and life aspiration. Discovering happiness brings spiritual consolations, joy, contentment and the assurance of reaching the complete Good. Happiness fascinates and unassumingly becomes the first longing of man. The orientation towards happiness is a natural, innate man's power, imprinted in human nature by the Creator. Within the Church it is this grace which encompasses man most fully. Its theological name is "salvation" - rediscovery of oneself in God, with God and for God.

\section{Happiness of heaven}

The Catechism of the Catholic Church teaches us: 'Those who die in God's grace and friendship and are perfectly purified live forever with Christ. They are like God for ever, for they „see him as he is, “(1 John 3:2) face to face ${ }^{777}$.

Man's heart is filled with a deep and constant longing, with desire and insatiable hunger for happiness, prosperity and bliss. It was always so it and so it will remain. The Book of Genesis contains the description of Eden (from the Sumerian term meaning "steppe“ or "plain“) where the first parents abided. It was the garden (in Hebrew "gan") with bountiful fruits from which the river flowed and four other rivers sprang, of which the Pishon flowed around the land of Hav'ilah, Gihon around the land of Cush (today's Ethiopia) whilst Hiddekel and Perat, identified nowadays as Tigris and Euphrates, flowed across

${ }^{76}$ Cf. R. Coste, Miłość która zmienia..., p. 15-32; W. Giertych, Szczęście się otrzymuje, "Pastores" (2011) nr 52, p. 7-14; M. R. Hinc, Logika świata a logika chrześcijańska, "Pastores" (2011) nr 52, p. 22-30.

77 Catechism of the Catholic Church, no. 1023. 
Mesopotamia ${ }^{78}$. It was this piece of land, this scenery and this natural bounty which have remained in people's memories forever to beget constant yearning for happiness which they truly could experience only there and in close relationship with $\mathrm{God}^{79}$.

A Christian has to achieve in his life something more than the worldly aim. Indeed, whoever limits his life to the earth, focuses on enjoying and using this life to the full, squeezing from it the last drop heedless of the needs of others.

People are like frogs living in a deep dark well from where they cannot see anything of the outside world. The believers are those who, despite living in such conditions, hear the lark's voice. And a miracle happens: they understand this singing... It tells about the suns and the moon, about stars, about mountains and valleys covered with trees, and about beauty which cannot be seen in the dim well. And they believe in this singing. Enchanted by it, they are trying to get out of the well onto the ground. They believe that their efforts have sense. They are convinced that a paradise exists. Yet, they do not neglect their worldly duties while heading for the paradise; and they are calling others to join in. We do not know exactly what is and how Christ's promise works. So we are going, putting our trust in Him for He said that it is worth doing. Talking about heaven is always incomplete, imperfect; it is always a clumsy attempt to express something beyond expression. Many people have found it impossible to describe the ineffable lavishness and bountifulness of the Paradise. Sir John Mandeville, in "The Travels" (1322) wrote: 'Of Paradise ne can I not speak properly. For I was not there. (...) But as I have heard say of wise men beyond, I shall tell you with good will. Paradise terrestrial, as wise men say, is the highest place of earth, that is in all the world. And it is so high that it toucheth nigh to the circle of the moon, (...) for she is so high that the flood of Noah ne might not come to her, (...). Many great lords have assayed with great will, many times, for to pass by those rivers towards Paradise, with full great companies. But they might not speed in their voyage(...) So that no mortal man may approach to that place, without special grace of God, (...) ${ }^{80}$. People have sought the Paradise for long centuries and they still do. The desire to achieve happiness, shared by the successive generations, establishes this direction of a life journey, accompanied

78 Gen 2: 8-14.

79 G. Berti, Zaświaty, tłum. G. Jurkowlaniec, Muza SA, Warszawa 2001, p. 14-16; Cf. T. Jelonek, O Raju i Złotym Wieku, Petrus, Kraków 2010.

80 Za: G. Berti, Zaświaty..., p. 16. 
with anxiety, which requires a constant quest for the place that is happy in itself. There were times when it seemed very close. Christopher Columbus in his "Journal of the Third Voyage" (1500) recounted: 'For in crossing this [equator] to the westward the vessels keep rising gradually toward the sky and then enjoy milder weather; and the needle varied a point on account of this mildness. The closer one comes to the equator, the higher they will rise and the greater the difference will be in the said stars and their orbits. (...) This is, I believe, where the paradise must be ${ }^{81}$.

The paradisiacal happiness will manifest itself by the joyous meeting of all people saved. Jesus has never specified or limited their number. Quite on the contrary, He said that there is a place for everyone and whoever is invited and does not come, the place shall remain empty. Jesus explained: 'No one has ascended into heaven but he who descended from heaven, the Son of man' ${ }^{82}$, If anybody wants to get into heaven, he may do it - be part of Hid Body - in His Church for He has descended onto the earth '(...) as Christ is the head of the church, his body, and is himself its Saviour ${ }^{83}$. And only He ascends so when being one with Him we shall get into Heaven with Him together. 'I am the way, and the truth, and the life; no one comes to the Father, but by $\mathrm{me}^{\mathrm{8}}$. Heaven was once visualized as the Temple of Jerusalem, with seven steps leading to it, as prophesied by Ezekiel ${ }^{85}$ Also in the well-known Jacob's dream there is a ladder with Angels ascending and descending. Jacob exclaims: 'Surely the Lord is in this place. (...) How awesome is this place! This is none other than the house of God, and this is the gate of heaven ${ }^{86}$. And it is already now that we can and must ourselves be heaven - the place where God dwells. By purifying ourselves of everything which is worldly and carnal, each of us, still carrying our bodies, in our hearts are THE heaven. '(...) Seek the things that are above, where Christ is, seated at the right hand of God. Set your minds on things that are above, not on things that are on earth ${ }^{87}$ and: 'But our commonwealth is

\footnotetext{
${ }^{81}$ Za: G. Berti, Zaświaty..., p. 19.

82 John 3:13.

${ }^{83}$ Eph 5:23.

${ }^{84}$ John 14:6.

${ }^{85}$ Ezek 40:26.

${ }^{86}$ Gen 28:10-17.

87 Col 3:1n.
} 
in heaven $(\ldots)^{88}$. The eternal life begins now, when man resurrects his will, his mind and his soul. Yet is it worth making this effort? Is it worth so much attention? Indeed, no one can tell us what heaven is as it is: 'What no eye has seen, nor ear heard, nor the heart of man conceived'89. We know of Abraham that he 'looked forward to the city which has foundations, whose builder and maker is $\mathrm{God}^{\prime 90}$. And Jesus said to his disciples: 'I go to prepare a place for you "91. The new life, given to us by the Resurrected Christ "is waiting", it already "is".

The greatest joy of heaven is to be near God, the fact that He is close to us for 'we shall see Him as $\mathrm{He}^{3{ }^{9}{ }^{92}}$. Heaven is the place reserved for the souls purified of all imperfection, bestowed with sanctifying grace, where "the vision of the beatified" - the contemplation of God, the "empireum" - is realized. St. Thomas Aquinas adopted this term from the Greek "empyros" which means "fiery". And such is heaven - a true love and glory ${ }^{93}$.

The happiness which Christ promises us, exceeds all our imagination. It is inconceivable and beyond the comprehension of those living on the earth. Already a psalmist found it difficult to describe, when writing: 'For as the heavens are high above the earth, so great is his steadfast love toward those who fear him; as far as the east is from the west, so far does he remove our transgressions from $\mathrm{us}^{\prime 94}$. Heaven is beyond any words, it is the thing our imagination cannot grasp and the meaning man cannot comprehend. It is the highest, utter and perfect blessedness that no one has ever known before ${ }^{95}$.

Our bodies will rise from the dead in the form in which Our Lord appeared. Thus we will be similar to the resurrected Jesus. We will live the life of angels, equal to them. Jesus says about those who died: 'they cannot die any more, because they are equal to angels and are sons of God, being sons of the resurrection ${ }^{96}$.

\footnotetext{
88 Phil 3:20.

891 Cor $2: 9$.

90 Heb 11:10.

91 John 14:2. Cf. G. Greshake, Już tutaj „tamten świat“, “Pastores” (2011) nr 52, p. 42-50.

921 John 3:2.

${ }^{93}$ G. Berti, Zaświaty..., p. 50-51.

94 Ps 103:11-12.

95 Z. J. Kijas, Niebo w domu Ojca - Czyściec dla kogo - Piekło w oddaleniu, Wydawnictwo WAM, Kraków 2010, p. 70-72.

${ }^{96}$ Luke 20:36.
} 
Heaven has its social and communal dimension as well. Martin Luther King once described his dream: when all of God's children, black men and white men, Jews and Gentiles, Protestants and Catholics, will be able to join hands and sing in the words of the old Negro spiritual: Free at last! Free at last! Thank God Almighty, we are free at last! Heaven will be like collecting all good crumbs into one bread, creating Unity of all bricks that we are. God will construct one perfect edifice from them. As St. Augustine affirmed: 'How great shall be that felicity, which shall be tainted with no evil, which shall lack no good, and which shall afford leisure for the praises of God, who shall be all in all! ${ }^{97}$.

St. John says: 'After this I heard what seemed to be the mighty voice of a great multitude in heaven, crying, "Hallelujah! Salvation and glory and power belong to our God, for his judgments are true and just ${ }^{29}$. Happiness is therefore made complete and man satiated at last in his desires and longings.

\section{Bibliography}

Arystydes, Apologia, in: M. Michalski, Antologia literatury patrystycznej, t. 1, Pax, Warszawa 1975, p. 90-91.

Augustyn św., O państwie Bożym, tłum. i oprac. W. Kornatowski, t. 2, Warszawa 1977. Augustyn św., O życiu szcześliwym, in: Dialogi filozoficzne, Warszawa 1953, t. 1, p. 17-20. Berti G., Zaświaty, tłum. G. Jurkowlaniec, Muza SA, Warszawa 2001.

Boriello L., Croce G. della, Secondin B., Duchowość chrześcijańska czasów wspótczesnych, seria: Historia duchowości, t. 6, tłum. M. Pierzchała, Wydawnictwo Homo Dei, Kraków 1998.

Carmody D. L., Carmody J. T., Mistycyzm w wielkich religiach świat, przekł. E. Łukaszyk, Wydawnictwo WAM, Kraków 2011.

Coste R., Miłość która zmienia świat. Teologia miłości, przekł. M. Stokowska, Fundacja Jana Pawła II, Rzym - Lublin 1992.

Domański J., Z dawnych rozważań o marności i pogardzie świata oraz nędzy i godności człowieka, PAN Instytut Filozofii i Socjologii, Warszawa 1997.

Ferry L., Człowiek-Bóg czyli o sensie życia, przekł. A. Miś, H. Miś, PIW, Warszawa 1998. Filipiak M., Biblia o człowieku, Towarzystwo Naukowe KUL, Lublin 1979.

Giertych W., Szczęście się otrzymuje, "Pastores” (2011) nr 52, p. 7-14.

97 Św. Augustyn, O państwie Bożym. Przeciw poganom ksiąg XXII, 22, 30.1, tłum. i oprac. W. Kornatowski, t. 2, Warszawa 1977, p. 613.

$98 \operatorname{Rev} 19: 1$. 
Greshake G., Już tutaj „tamten świat”, “Pastores” (2011) nr 52, p. 42-50.

Grzegorz z Nazjanzu św., Mowa 16. Po klęsce gradowej w obecności milczącego Ojca, nr 2, in: Grzegorz z Nazjanzu św., Mowy wybrane, Pax, Warszawa 1967.

Hart D. B., Chrześcijańska rewolucja a złudzenia ateizmu, przekł. A. Gomola, Wydawnictwo WAM, Kraków 2011.

Herka R., O chrześcijańskiej miłości i szczęściu, “Obecni” (2012) nr 24, p. 5-9.

Hinc M. R., Logika świata a logika chrześcijańska, "Pastores” (2011) nr 52, p. 22-30.

Iniesta H., Jezus Chrystus - herold szczęśliwości, "Communio" (1962) nr 2-3 (92-93), p. 3-12.

Jan Chryzostom św., Miłosierdzie. Wypisy z „Homilii na Ewangelię według św. Mateusza”, oprac. E. Staniek, Wydawnictwo WAM, Kraków 2004.

Jelonek T., O Raju i Złotym Wieku, Petrus, Kraków 2010.

Johnson Ph., M(i)arkowanie szczęścia, (The Daily Telegraph, 23 XI 2010), “Forum” (2011) nr 1, p. 16-17.

Kant I., Krytyka czystego rozumu, II, II, II, tłum. R, Ingarden, t. 2, PWN, Warszawa 1957.

Kapuściński R., Cesarz, Biblioteka Gazety Wyborczej, Warszawa 2008.

Kijas Z. J., Niebo w domu Ojca - Czyściec dla kogo - Piekło woddaleniu, Wydawnictwo WAM, Kraków 2010.

Kopsztejn M., Chrześcijański paradoks szczęśliwego ubóstwa, "Pedagogika Katolicka" (2011) nr 8, p. 128-136.

Kunka S., Być szczęśliwym dziś. Marzenie czy rzeczywistość?, "Obecni” (2012) nr 24, s. 27-39.

Langer K., Szczęście, in: Praktyczny słownik biblijny, A. Grabner-Haidera (ed.), przekł. T. Mieszkowski, P. Pachciarek, Pax, Warszawa 1994, k. 1265-1266.

Leick R., Siódmego dnia odpocznij. Rozmowa z Tomaśem Sedlaćkiem ("Der Spiegel”, 19 III 2012), "Forum" (2012) nr 14/15, p. 4-6.

Meches F., Bogactwo jest wyzwaniem. Rozmowa z rabinem Szalomem Berem Stamblerem, “Uważam Rze” (2011) nr 37, p. 84-85.

Michoń P., Ekonomia szczęścia, Dom Wydawniczy Harasimowicz, Poznań 2010.

Nasiłowski P., Odmienieni przez smutek, “Pastores” (2011) nr 52, p. 97-101.

Noumen H. J. M., Powrót syna marnotrawnego, Poznań 2000.

Olbrycht K., Religia a wspieranie rozwoju człowieka, in: Religia a sens bycia człowiekiem, Z. J. Zdybicka (ed.), Redakcja Wydawnictw KUL, Lublin 1994.

Pancerz R. M., Miejsce smutku w duchowości chrześcijańskiej. Świadectwa wielkich pisarzy monastycznych od Ewagriusza do Jana Klimaka, "Polonia Sacra" (2011) nr 29, p. 277-290.

Rybicki A., Świątobliwy, ale nieszczęśliwy, "Pastores” (2011) nr 52, p. 81-88.

Strzelczyk G., Szczęście Jezusa, "Pastores” (2011) nr 52, p. 15-21.

Szamota S., Święty Benedykt, jego dzieło i „Reguła”, Wydawnictwo Panta, Lublin Frydrychowice 1991. 
Szczur P., Problematyka społeczna w późnoantycznej Antiochii na podstawie nauczania homiletycznego Jana Chryzostoma, Wydawnictwo KUL, Lublin 2008.

Ślipko T., Etos chrześcijański. Zarys etyki ogólnej, WAM, Kraków 1974.

Tomasz z Akwinu św., Szczęściem poznanie Boga, in: Summa filozoficzna (Contra Gentiles), Kraków 1933, ks. III, p. 319-325.

White K., Dahl D. W., To Be or Not Be? The Influence of Dissociative Reference Groups on Consumer Preferences, "Journal of Consumer Psychology" (2006) vol. 16, nr 4, p. 404-414.

Zdybicka J., Religia i religioznawstwo, Lublin 1988. 